\title{
Information Management of the Risks and Threats of the Covid-19 Pandemic
}

\author{
A. V. Aleinikov ${ }^{a, *}$, D. A. Maltseva ${ }^{a, * *}$, and A. N. Sunami ${ }^{a, * * *}$ \\ ${ }^{a}$ St. Petersburg State University, St. Petersburg, 199034 Russia \\ *e-mail:a.alejnikov@spbu.ru \\ **e-mail:d.maltseva@spbu.ru \\ ***e-mail:a.sunami@spbu.ru
}

Received July 3, 2020

\begin{abstract}
This study examines information risk management models in the context of the pandemic crisis, the mechanisms of circulation of information about COVID-19, and the issues about the relationship between risk perception and information trust, which are the key factors of successful response to a pandemic. The article focuses on the basic information strategies related to risk reflections on the coronavirus pandemic.
\end{abstract}

Keywords: information, pandemic, COVID-19, risks, risk reflections, information strategies

DOI: $10.3103 / \mathrm{S} 0147688220030090$

\section{INTRODUCTION}

In modern science, much attention is paid to discussions around the phenomenon of the coronavirus pandemic, questions about the models and prospects for the development of various spheres of society, about the degree of institutional impact of COVID-19 on changes in political and expert discourse, about "unpredictable instability as a new normalcy," about the transformation of communication and information platforms. Instead of conventional information models of decision making, rapidly spreading conspiracy theories emerge in health care [1]; anti-scientific information and irrational mythical threats and fears circulate [2].

A detailed theorization of the social phenomenon of epidemics and its influence on historical development was carried out in the monumental work of Fernand Braudel, who wrote that man is a target for an incessant bombardment of pathogenic elements, and the history of humans, in fact, is formed by a gigantic struggle between man and microbes, bacilli, and viruses [3, p. 57].

Man's fight against epidemics has been fought in different ways and with varying degrees of success. However, the pandemic that is taking place before our eyes is unique; it not only has exacerbated the existing social and political contradictions many times over, but has also generated new ones [4] and exposed "risks for which the most advanced and most technologically advanced states were not ready" [5].

The "viral revolution," according to the consensus forecast of many experts, will lead to a reduction in office workers, the reformatting of transport and production chains, the transition of companies from hierarchical structures to cloud-type structures, to fundamentally new labor relations, and tectonic shifts in the labor market. The pandemic, as a source of significant institutional change, has become the most serious stress test for vital information risk management. The literature emphasizes that in the conditions of "covidizatsiyu" the dissemination of information exclusively from the top down, stereotypes, and paternalism undermine trust, create fear, and alienate society, whose support is critical for a successful response to a crisis/pandemic situation [6]. Thus, a new methodological focus is needed, involving the study features of information flows in a crisis situation, new risks, and threats that arise in the new configuration of interaction and exchange of knowledge and information in a pandemic. However, many of the nuances in the study of the characteristics and mechanisms of perception of information about risks and reactions to them remain unclear, despite the fact that "thinking in terms of risk is becoming more or less inevitable" [7].

This study is an attempt to examine the phenomenon of modern information models of risk management in the context of the "pandemic-economic" crisis. The aim of the study is in line with the change in the doctrine of information management as the management of information resources of society and the concept of informatics carried out by R.S. Gilyarevsky [8] and his scientific school.

The research objectives are as follows: (1) highlight the mechanisms and models of information dissemination in crisis situations, which are characterized by 
breaks in the "constellation of spatial fragments, functional pieces, and social segments" [9, p. 379] and (2) apply the concept of risks and dangers as a methodological toolkit to analyze the characteristics of the role and functions of information in the production of the responses of people to the threat of a pandemic.

\section{INFORMATION AND TRUST IN THE CONTROL SYSTEM PANDEMIC RISKS}

The spread of COVID-19 has given new impetus to research on the political practices of the social construction of "pandemic" risks and threats in the discourse of the sociology of information. It seems that the increasing research efficiency and social relevance of future risks posed by COVID-19 problematizes the issues of theoretical and methodological foundations for studying the processes of interrelation of risk perception and trust in information [10].

The victory over viruses, according to A. Shcherbak, is evidence of the development of not only public hygiene, medicine, science, and education, but also the rationalization of control systems [11, p. 5].

This kind of rationalization also determines the ways in which information about Covid-19 circulates, which can both cause and intensify a "pandemic of panic," as well as bring social meaning and responsibility.

The authors of this article are in agreement with the thought of the famous sociologist Richard Lachman, who believes that "people are more likely to make sacrifices if they feel confident that leaders are honest with them and that hardship concerns everyone. When there is no such confidence, the requirement to keep your distance will be ignored. People will begin to attack others, accusing them of causing the disease or attempts to cash in on it" [12].

The starting point of our research is the concept of a "risk society," through the prism of which information management models and strategies can be effectively investigated in the context of the fight against the pandemic.

In the classic work of W. Beck [13] the concept of a "risk society" designates such a stage of development of society for which the key is reconfiguration of political and social systems, taking the risks associated with human activity and technology into account, and attention to the topic of distribution of risks and threats becomes decisive. Particular emphasis is placed on the relatively unexplored problems of social perception of information about environmental, biological, or criminogenic hazards and its role in modeling ways to combat threats.

In this connection, the theoretical explications of P. Sztompka about different types of risk manifestations in the act of trust appear to be relevant. We must proceed from the fact that "in addition to the risk associated with the irresponsible or harmful behavior of others, giving trust to someone who does not deserve it leads in addition to negative psychological consequences.... The risk of exceeding the use of trust is most tangible here and is not limited to feelings of discontent. Together with the entrusted object, we give part of our freedom ... Trust, in order for it to be justified, must be accompanied by a security guarantee" [14, pp. 100-103].

One can agree with the opinion of the authoritative political scientist F. Fukuyama, who calls social trust one of the decisive factors in a successful response to a pandemic [15].

Researchers have previously noted mistrust of official information in various epidemics [16, 17].

During the spread of COVID-19, sociologists found that $56 \%$ of the respondents do not trust official statistics on the spread of coronavirus, of which $68 \%$ believe that the information is being distorted; $27 \%$ stopped trusting official information during the development of the crisis [18].

As an example, "serological surveys" (sociological questionnaire plus analysis data) conducted in St. Petersburg show that there are actually ten times more people who became sick in St. Petersburg than officially registered cases [19].

Similar data (exceeding the number of recovered cases by approximately ten times) were obtained as a result of studies of residents of Geneva, Finland, Denmark, Sweden, Spain, and New York State [20].

The main sources of mistrust are contradictions in the information field and a sense of injustice and resentment; $57 \%$ of respondents cite social networks among the main sources of information about the pandemic, while $43 \%$ cite federal TV channels.

Contradictions and gaps in the information field are associated with the unreliability of information about the severity of the disease ("common ARVI" or mortal danger for everyone), about the means of protection and prevention, the inconsistency of statements by officials about the measures that are being introduced, and misunderstanding of government decisions (especially unpopular ones). Thus, a vicious circle of distrust and disorientation is formed: at each next loop, the balance shifts towards distrust of information about the virus, displacing other topical issues from the information agenda [18].

In the information realities of modern society, there is a kaleidoscope of the epidemic's production of a wave of irrationality, often directly directed "at" rational "doctors, hospitals, and sanitary measures of the authorities." Quite often pandemics "were accompanied by "pandemics of hatred," both from the masses and from the authorities" [11, p. 21].

In this regard, the key features formulated by R.S. Gilyarevsky are "Having arisen and rapidly improved, electronic information technologies penetrate into all pores of social mechanisms and have a 
strong reverse effect on social production ... With their use, you can look into the depths of social processes hidden from us until now and influence the operation of their objective laws" [8, p. 201].

\section{INFORMATION UNCERTAINTY AND MANAGEMENT OF RISKS}

According to N. Luhmann, a distinctive feature of the study of the phenomenon of risk in the information society is its comprehension "only in accordance with the meaning of communications, including, of course, messages in communication about individually made decisions" [21, p. 146].

Hence, there is another significant conceptual complexity, that of how to most effectively identify and classify key information risks in a pandemic.

One of the approaches described by O'Neill is identification of four types of understanding and assessment of the risks of an information system, that is, those who take risks, those who are risk tolerant, those who deny risk, and those who identify risks [22].

First, we are talking about the effectiveness of the response in a crisis epidemiological situation to unknown risks, whose perception significantly affects the processes of anti-crisis political management. This situation can be determined by the ability to develop original strategies and models of work with appropriate risk reflections about the epidemic and measures to fight against them [23].

Predicting risks and dangers in this case turns out to be not only an important indicator of maintaining the stability of life even in an emergency, but also a variable in the process of making and legitimizing technologically understandable and "transparent" management decisions and practices under conditions of uncertainty.

As studies by D. Kahneman and his colleagues have shown, various social subjects are "overly" information-satiated ... and tend to accept that extreme behavior is modal ... and some types of information that scientists consider appropriate and informative are usually ignored by people.” [24].

Information uncertainty in the situation with a pandemic consists in frightening forecasts, the formation of an attitude towards the perception of the unfamiliar as dangerous, mistrust of information sources, the loss of the ability to make a realistic assessment of the situation, and overestimates of the significance of danger.

When a public health emergency occurs, people may need food, clothing and shelter, safe drinking water, and medical care, but first and foremost they need to know how to best avoid risks so that morbidity and mortality can be minimized [6].

It is no coincidence that in the conditions of "state isolation" and the closure of borders, information flows, on the contrary, are increasing. Thus, during the COVID-19 pandemic The Russian Academy of Sciences has signed an agreement with a number of national academies on the prompt exchange of scientific information about its origin and the effectiveness of treatment methods [25]. Special sections on COVID-19 have been created on the websites of leading national academies of sciences; the World Health Organization has developed a tool for analyzing behavioral factors associated with coronavirus, which allows one to simply and quickly monitor the attitudes of the population, as a result of which information policy is adjusted and carried out in a more targeted manner to increase the effectiveness of influencing behavior and a web page dedicated to myths about the outbreak of a viral epidemic was created [26].

Based on one of the central constructs of U. Beck's "risk society," that is, Ignorance," it seems clear that this ignorance and pressure from the growing uncertainty of the pandemic have strongly impacted a number of political and social institutions. Moreover, at the macro level, radical uncertainties have become a threat to legitimacy and a serious obstacle to control over institutional systems.

\section{INFORMATION STRATEGIES AND PANDEMIC RISK REFLECTION}

In describing the basic information strategies associated with reflections of the COVID-19 pandemic, we will rely on the research program of P. Ibarra and D. Kitsuse, who proposed an interpretive model of social problems, which, in contrast to the normativefunctionalist concept, focuses on how people react to frustrating events [27]. From these points of view, the main reactions to the pandemic are the problematization and de-problematization of COVID-19. At the same time, it is especially necessary to highlight the rhetorical idioms and counter-rhetorical strategies that are used by content producers in building a discourse around the topic of the virus.

At the same time, attribution of a problematic character to the coronavirus, as well as a counter-rhetorical denial of problematicity in terms of content, inherits the "birthmarks" of previous debates. We cannot ignore the fact that the statement of the problem and discursive strategies in the process of a communicative act cannot be considered without taking the contextual framework into account, or, as A. Schütz puts it, "taken for granted," and the interpretation of the world that was close to the sides of communication before this; the discourse built around the pandemic is preceded by something that largely determines its form [28].

It is clear that the consumer and disseminator of information about the coronavirus is by no means neutral. He already has a certain information background regarding diseases and drugs, or what is designated in science as a tendency to confirm his point of view (confirmation bias), that is, a person's focus on 
finding such information that is consistent with an opinion already formed in him.

Naturally, the perception and interaction with the topic of COVID-19 in the information space are superimposed on a whole set of rumors, stereotypes, conjectures, and myths about public health that circulate in social discourse. Moreover, they make up a significant part of it. A side effect of the successful competition between hearing and fact was the growth of academic publications devoted to the mechanisms of rumor spreading and their influence on the perception of any medical information, as well as the problem of the reliability of data, that is, "true" and "fake." A striking example of this is the topic of vaccination and the promotion of the anti-vaccination movement [29].

It is no coincidence that in May 2020, the Prosecutor General's Office of the Russian Federation was forced to ask for a block of access to sites where false information was posted about the artificial nature of the coronavirus, which was allegedly created to eliminate the problem of overpopulation of the Earth, and the need to refuse to be vaccinated [30].

Thus, the impact of anti-vaccine content on measures taken to combat the coronavirus, in particular on planned vaccination, can be labeled as an independent information threat aimed at blocking or sabotaging the ongoing efforts to combat the epidemic.

In defining the features of the modern information environment, N. Luhmann noted that "the truth (provability or irrefutability) of information ... appears ... completely replaceable, as a product of a decision and as conditioned by motives... In contrast to scientific information, mass media information is not subject to such reflection, in which it should be stated in a true way that untruths can be excluded even before the truth is asserted "[31, p. 62-64].

One illustration of this thesis of the German sociologist is the refusal of many parents around the world to immunize their children, provoked misinformation about the link between childhood vaccinations and autism. This, according to experts, led to "a marked increase in the number of vaccine-preventable diseases, as well as unnecessary public spending on research and public awareness campaigns aimed at correcting the situation" [32].

Even at this moment, when the first steps are being taken to develop and test a vaccine against COVID-19 and it is very far from its mass use, the expert community is already expressing concern about the perception of the population on this measure. Thus, according to a study conducted by The Associated PressNORC Center for Public Affairs Research, only $49 \%$ of American citizens plan to be vaccinated against coronavirus when the vaccine becomes available, $20 \%$ do not plan to be vaccinated, and $31 \%$ have not yet decided [33]. A poll by VTsIOM showed that $59 \%$ of Russians will be vaccinated against COVID-19, provided that it is proven effective, while $35 \%$ believe that they will not get vaccinated. Moreover, $70 \%$ insist on voluntary vaccination [34].

Thus, having considered "anti-vaccine content" as one of the components of the COVID-19 framework, we can move on to rhetorical idioms and counter-rhetorical strategies used in the modern information space.

As already noted, P. Ibarra and D. Kitsuse have distinguished several rhetorical idioms through which a problematic status is assigned to an event or phenomenon: the rhetoric of loss, the rhetoric of empowerment, the rhetoric of unreasonableness, the rhetoric of disaster, and finally, the rhetoric of danger. The last three of these can be considered the most relevant to our topic.

The Rhetoric of danger is used in relation to those conditions that pose a threat to human health and safety; the word markers are disease, risk, and infection. In our case, pandemic is such a word, which has become the main trend of Google searches around the world, since the head of the WHO announced that what is happening can be described as a pandemic. At the same time, the WHO stressed that describing the situation as a pandemic does not change anything both in relation to the measures taken by the organization and governments, and in relation to the assessment of the risks produced by the virus. In general, the official position of the WHO emphasizes the danger, but not the catastrophic nature of the situation, as much as possible.

Nevertheless, two other rhetorical idioms are also noteworthy, even if their use is rather auxiliary in nature.

The rhetoric of unreason is used in the discussion of the coerciveness of the taken measures, because it assumes that some groups of people need guardianship in relation to a particular problem due to ignorance or low social responsibility and this requires additional measures that are not only not limited to raising awareness, but accompanied by strengthening control.

The Rhetorical idiom of distress is used to highlight the problem of interest from the entire range of dangers, to give it the most threatening or integral character in comparison with the rest. Throughout the entire period of the epidemic, in different locations, there have been injections of "catastrophic" information about the coronavirus in the form of audio and video recordings, text and graphic messages from "eyewitnesses" spread through social networks and instant messengers.

Thus, we can conclude that problematization of COVID-19 was carried out through the use of the rhetoric of danger, which was periodically supported by the rhetorics of distress and unreason.

Let us consider the most typical counter-rhetorical strategies that worked for deproblematization of COVID-19. Following P. Ibarra and D. Kitsuse, we classify the counter-rhetorical strategies used in the 
construction of "covid discourse" as sympathetic and nonsympathetic strategies.

Sympathetic strategies do not question the "problematic nature" of the pandemic, but rather present its individual aspects in such a way that fighting it seems impossible or unnecessary. These, in our opinion, include strategies: naturalization, costs, declaration of powerlessness, perspectivization, criticism of tactics.

Dissenting strategies reject claims that the spread of coronavirus is a problem. In this pool, the "anti-typing," "refuting stories," "insincerity," and "hysteria" strategies can be distinguished.

Let's start with naturalization strategies, which at the initial stage of the spread of the virus was quite typical. It is a presentation of the problem as a kind of natural, common, and inevitable phenomenon. The standard reasoning was comparison with seasonal flu.

As an example, on his Twitter account, American President Donald Trump wrote: "Last year 37000 Americans died of seasonal flu, nothing closed, think about it" [35]. A few days before the World Health Organization announced a pandemic Brazilian President Jair Bolsonaro "mocked" COVID-19, claiming that fears were exaggerated and the flu killed many more people [36].

Other commonly used discourse strategies are addressing the cost problem and a strategy that is close to it, criticism of tactics, whose main idea is that the quarantine measures taken against the coronavirus are more expensive for the economy than the damage caused by the virus and the costs incurred as a result of the decrease in production and unemployment may take more lives than the virus. An example of such a model is the study by an expert in the field of risk management, University of Bristol Professor F. Thomas, who has been widely cited by the world's leading news agencies, in which he suggests that the recession caused by restrictive measures against the coronavirus is more deadly than COVID-19 itself [37].

Based on the results of S. Preston's research, which revealed a directly proportional dependence of the average life expectancy of citizens on the level of the country's GDP, F. Thomas concluded that the suspension of the economy for more than 2 months will do more harm than good in terms of saving human lives.

The declarations of impotence strategy is based on scientific information about the spread of viruses, that is, denying the reality of serious success in the fight against coronavirus until the entire population has been infected naturally, or until the moment of total vaccination. One example is the statement by the head of the Information Center for monitoring the coronavirus situation, Alexander Myasnikov: "The infection will take its toll, we will still be ill. Those who are supposed to die will die."

The antityping strategy, i.e., the denial of the pandemic as a large-scale social problem in favor of its presentation as a risk for certain groups of the population is used much more widely. This is certainly facilitated by the fact that the main risk group is the elderly.

Numerous conspiracy theories form the basis strategies of insincerity, that is, the idea of the existence of hidden beneficiaries of the pandemic, the global behind-the-scenes use of the coronavirus as a way to gain power [38].

Finally, the hysteria strategy, which indicates the irrationality of fears about coronavirus, is often used by official health care personnel if the situation seems to be out of control to them. The confusion among epidemiologists about the usefulness or uselessness of mass wearing of medical masks, which is presumably positively related to the supply-demand ratio for this product, is clear evidence of this. Thus, we can note a wide variety of discourse strategies aimed at deproblematization of the pandemic.

We will now discuss the sides of this communicative act. The main sources of information risks, including information that can misinform an inexperienced consumer or researcher include scientists, journalists, and scientific news relays. The latter group includes both representatives of authorities at all levels and ordinary consumers of scientific data [39].

As for the end consumers of information about the coronavirus, the results of a study of the content of the Twitter social network that was conducted in February 2020 are interesting [40]. A group of the 1000 most viewed posts containing the coronavirus tag was highlighted and all messages were split according to their different types of information: fake information; mixed information; information containing both truth and falsehood; scientifically sound information; verified information; facts. It was found that false information is published much more often, but is retransmitted much less often than scientifically based information.

The public opinion of Russians about the coronavirus, whose formation, in the final analysis, is aimed at the entire set of the rhetorical idioms and counterrhetorical strategies described above, demonstrates ambiguous trends. At the beginning of April 2020, a special portal of official information on coronavirus (stopkoronavirus.rf) conducted a survey, according to which $46 \%$ of the respondents developed a strategy of reasonable trust in relation to information about COVID-19. The CoronaFOM project launched by the Public Opinion Foundation, which measures the perceptions of Russians for everything related to coronavirus according to 40 indicators on a daily basis, demonstrates that the integral indicator "ignoring the disease," which includes those respondents who are not personally afraid of getting sick and whose majority is not afraid of getting sick, has grown with some fluctuations, reaching a peak of $46.9 \%$ by June 11 [41].

It should be noted that at the level of everyday information practices, we are dealing with multiple 
manifestations of discrepancies in the description of the risks, dangers, and threats of the pandemic by those who make management decisions (risks are considered as deviations from a given norm) and the perception of risks by those affected by them [42]. M. Dean [43] noted that in the information management coordinate system associated with the spread of coronavirus, "the concept of risk is understood as a special representation that presents reality in a form that makes it accessible to impact and intervention."

\section{CONCLUSIONS}

The focus of the research interest of the authors of this article was primarily directed at the phenomenon of modern information models of risk management in the context of the "pandemic-economic" crisis, and on the identification of mechanisms and models of a complex system for informing people in crisis situations.

A transformation of communication and information platforms is occurring in the modern realities of the spread of coronavirus and viral infections and counteractions to it. In covidization conditions information management of risks becomes vital by studying the features of information flows in a crisis situation, the specifics of the presentation of new threats that arise in a new configuration of interaction, and exchange of knowledge and information in the pandemic. Obtaining information about the threat of a pandemic (protective actions of individuals and organizations, information from the government and independent media, regulatory, and information measures of the government) is one of the main measurements of the effectiveness of measures taken by society and the state during the COVID-19 epidemic.

Our study suggests that the methods of circulating information about COVID-19 and the mechanisms of intensive conversion of information into emotional presentations can lead to both a "pandemic of panic" and to the strengthening of social responsibility. One important link in this process is the relationship between risk perception and trust in information, which acts as a critical factor in a successful pandemic response. The study of communication strategies shows that contradictions and gaps in the information field are the main source of mistrust that cause inflation of irrationality; forced digitalization of information technologies caused by the epidemic is changing the methods and forms of social management and is also a source of risks and dangers.

Everyday practices are always linked to the perception of unknown risks, whose forecasting turns out to be the most important information component in the process of making and legitimizing management decisions and practices under conditions of uncertainty. Information uncertainty in this situation with the pandemic consists in the formation of an attitude towards the perception of the unfamiliar as dangerous, on distrust of information sources, and the loss of the ability to make a realistic assessment.

Ignorance and pressure from the growing uncertainty of the pandemic puts pressure on political and social institutions; incomplete information or misinformation becomes a threat to legitimacy and a serious obstacle to control over institutional systems.

It can be argued that the main information responses to the pandemic are the problematization and de-problematization of COVID-19. In the course of this study, it was found that scientific information about the coronavirus contains contradictory data, which is replaced by other information, and can be converted into an independent information threat aimed at blocking or sabotaging the ongoing efforts to combat the epidemic.

\section{FUNDING}

This study was carried out under a grant from the Russian Science Foundation (project No. 19-18-00115) in the part of an article written by A.V. Aleinikov and A.N. Sunami, and with the financial support of the Russian Foundation for Basic Research (project no. 20-011-00393; article written by D.A. Maltseva).

\section{CONFLICT OF INTEREST}

The authors declare that they have no conflicts of interest.

\section{REFERENCES}

1. Volkin, S., During the covid-19 pandemic, 2020. https://hub.jhu.edu/2020/05/08/thomas-rid-disinformation-in-covid-19-pandemic/. Accessed July 1, 2020.

2. Weible, C., Nohrstedt, D., Cairney, P., et al., COVID-19 and the policy sciences: Initial reactions and perspectives, Policy Sci., 2020, vol. 53, no. 2, pp. 225-241.

3. Brodel', F., Material'naya tsivilizatsiya, ekonomika i kapitalizm, $X V-X V I I I v v$. (Material Civilization, Economics, and Capitalism, XV-XVIII Centuries), vol. 1: Struktury povsednevnosti: Vozmozhnoe i nevozmozhnoe (Structures of Everyday Life: The Possible and the Impossible), Moscow: Ves' Mir, 2007.

4. Krastev, I., Has tomorrow come?, Ross. Global'noi Polit., 2020, no. 3, pp. 42-62.

5. Medvedev, D.A., Security cooperation during the novel coronavirus pandemic, Ross. Global'noi Polit., 2020. https://globalaffairs.ru/articles/bezopasnost-v-periodpandemii/. Accessed July 1, 2020.

6. Toppenberg-Pejcic, D., Noyes, J., Allen, T., et al., Emergency risk communication: Lessons learned from a rapid review of recent gray literature on Ebola, Zika, and yellow fever, Health Commun., 2019, vol. 4, pp. 437-455.

7. Giddens, E., Fate, risk, and safety, Thesis, 1994, no. 5, pp. 107-134.

8. Gilyarevskii, R.S., Osnovy informatiki: Kurs lektsii (Fundamentals of Informatics: Course of Lectures), Moscow: Ekzamen, 2003. 
9. Kastel's, M., Informatsionnaya epokha: Ekonomika, obshchestvo i kul'tura (Information Age: Economy, Society, and Culture), Moscow: Vyssh. Shk. Ekon., 2000.

10. Brown, P. and Galantino, M., Theorising - problematising categories: Understanding the Covid-19 pandemic through the sociology of risk and uncertainty, Eur. Sociol., 2020, vol. 1. https://www.europeansociologist.org/issue-45-pandemic-impossibilities-vol-1. Accessed July 1, 2020.

11. Shcherbak, A., Viruses, epidemics, and modernization theory: Friends or foes?, Preprint M-78, St. Petersburg: European University in St. Petersburg, 2020.

12. Lachmann, R., First-Class Passengers on a Sinking Ship: Elite Politics and the Decline of Great Powers, Hangzhou: Zhejiang Univ. Press, 2020.

13. Beck, U., Risk Society: Towards a New Modernity, SAGE Publ., 1992.

14. Shtompka, P., Doverie - osnova obshchestva (Trust: The Foundation of Society), Moscow: Logos, 2012.

15. Fukuyama, F., The pandemic and political order, Foreign Affairs, 2020, vol. 99, no. 4, pp. 26-32.

16. Atlani-Duault, L., Ward, J., Roy, M., et al., Tracking online heroisation and blame in epidemics, Lancet Public Health, 2020, vol. 5, no. 3, pp. 137-138.

17. Tirkkonen, P. and Luoma-aho, V., Online authority communication during an epidemic: A Finnish example, Public Relat. Rev., 2011, vol. 37, no. 2, pp. 172-174.

18. Puzzle of Trust, Sociological Anti-Crisis Center, 2020. https://pltf.ru/2020/06/16/issledovanie-platformypazl-doverija/. Accessed July 1, 2020.

19. Serological Study of the Spread of COVID-19 in St. Petersburg, 2020. https://eusp.org/sites/default/files/inline-files/euspb-scandinavia-serosurvey-presentation19.06-final.pdf. Accessed July 1, 2020.

20. Bobrovitz, N., Arora, R., and Yan, T., Lessons from a rapid systematic review of early SARS-CoV-2 serosurveys, MedRxivpreprint, 2020. https://www.medrxiv.org/content/10.1101/2020.05.10.20097451v1.full.pdf. Accessed July 1, 2020.

21. Luman, N., Concept of risk, Thesis, 1994, No. 5, pp. $135-160$.

22. O'Neill, P., Developing a risk communication model to encourage community safety from natural hazards, The Fourth NSW Safe Communities Symposium, Sydney: NSW, 2004.

23. Ho, C., Chee, C., and Ho, R., Mental health strategies to combat the psychological impact of Covid-19 beyond paranoia and panic, Ann. Acad. Med. (Singapore), 2020, vol. 49, no. 1, pp. 1-3.

24. Kahneman, D., Slovic, P., and Tversky, A., Judgment under Uncertainty: Heuristics and Biases, New York: Cambridge Univ. Press, 1982.

25. Joint Statement by the Academies of Science and Medicine: Critical Need for International Cooperation during the Covid-19 Pandemic, 2020. http://www. ras.ru/news/shownews.aspx? $\mathrm{id}=7 \mathrm{ed} 7 \mathrm{~d} 3 \mathrm{dd}-0 \mathrm{bff}-4 \mathrm{~b} 9 \mathrm{~b}-$ a8be-771baaeac961. Accessed July 1, 2020.

26. Kubrak, T.A. and Latynov, V.V., Information Policy in Crisis Situations: Content Shaping and Communication Management, 2020. http://www.ipras.ru/cntnt/rus/institut_p/covid-19/kommentarii-eksp/t-a-kubrakv-v-latinov-informaci.html. Accessed July 1, 2020.

27. Ibarra, P.R. and Kitsuse, J.I., Vernacular constituents of moral discourse: An interactionist proposal for the study of social problems, in Constructionist Controversies: Issues in Social Problems Theory (Social Problems and Social Issues), Loseke, D.R. and Best, J., Eds., Hawthorne, NY: Aldine de Gruyter, 1993, pp. 21-54.

28. Shyutts, A., Equality and the semantic structure of the social world, Sotsiol. Zh., 2002, no. 4, pp. 5-45.

29. Jamison, A., Broniatowski, D., and Quinn, S., Malicious actors on Twitter: A guide for public health researchers, Am. J. Public Health, 2019, vol. 5, pp. 688692.

30. The General Prosecutor's Office of the Russian Federation Demands to Restrict Access to Sites Spreading False Information about Coronavirus Infection. http://www.genproc.gov.ru/smi/news/genproc/news1841234/. Accessed July 1, 2020.

31. Luhmann, N., The Reality of the Mass Media, Stanford Univ. Press, 2000.

32. Lewandowsky, S., Ecker, U., Seifert, C., et al., Misinformation and its correction: Continued influence and successful debiasing, Psychol. Sci. Public Interest, 2012, vol. 13, no. 3, pp. 106-131.

33. Expectations for a COVID-19 Vaccine. http://www.apnorc.org/projects/Pages/Expectations-for-a-COVID-19Vaccine.aspx/. Accessed July 1, 2020.

34. Vaccination against COVID-2019: Prospects and Expectations. https://wciom.ru/index.php?id=236\&uid= 10284. Accessed July 1, 2020.

35. Like the Flu? Trump's Coronavirus Messaging Confuses Public, Pandemic Researchers Say. https://www.reuters.com/article/us-health-coronavirus-mixed-messages-idUSKBN2102GY. Accessed July 1, 2020.

36. Pfrimer, M. and Barbosa, J., Brazil's War on COVID-19: Crisis, not Conflict-Doctors, not Generals, Dialogues Hum. Geogr., 2020. https://journals.sagepub.com/doi/ full/10.1177/2043820620924880. Accessed July 1, 2020.

37. Thomas, P., Recession more deadly than coronavirus: The impact of a global economic recession could cause deaths around the world, Inst. Arts Ideas, 2020, vol. 87, no. 1. https://iai.tv/articles/is-a-recession-more-deadly-than-coronavirus-auid-1397. Accessed July 1, 2020.

38. 5G, Vaccines and Digital Enslavement: New Coronavirus but Old Conspiracy Theories, 2020. https://www.bbc.com/russian/features-52256074. Accessed July 1, 2020.

39. Scheufele, D. and Krause, N., Science audiences, misinformation, and fake news, Proc. Natl. Acad. Sci., 2019, vol. 116, no. 16, pp. 7662-7669.

40. Pulido, C., Villarejo-Carballido, B., Redondo-Sama, G., and Gómez, A., Covid-19 infodemic: More retweets for science-based information on coronavirus than for false information, Int. Sociol., 2020, vol. 35, no. 4, pp. 377392.

41. Integral indicators CoronaZond, 2020. https://covid19.fom.ru/post/integralnye-indikatory. Accessed July 1, 2020.

42. Aleinikov, A.V., Reflexive risk tracking and social order in the realities of the "digital society," in Vozmozhnosti $i$ ugrozy tsifrovogo obshchestva. Sbornik nauchnykh statei (Opportunities and Threats of the Digital Society. Collection of Scientific Articles), Yaroslavl: Yarosl. Gos. Univ., 2019, pp. 7-11.

43. Dean, M., Governmentality: Power and Rule in Modern Society, SAGE Publ., 2010. 